\title{
First hatchery bred streaked spinefoot rabbitfish (Siganus javus) in Sabah, Malaysia
}

\author{
Jeremy Tan* \\ Bayu AquacultureSdn. Bhd, P. O. Box 22477, 88784 Luyang, Kota Kinabalu, Sabah, Malaysia.
}

${ }^{*}$ Corresponding author: info-merc@echoresorts.com

\begin{abstract}
The present study aims to expand the market potential of the streaked spinefoot rabbitfish (Siganusjavus) in Malaysia and provide consumers more choices of affordable protein source from aquaculture. Spawning hehavior of S.javus was recorded in a week after the new moon in October 2019 and January 2020. Spawning occurred between midnight and early morning and the eggs hatched about 16 to 18 hours later. Throughout the incubation and larvae rearing period, water temperature was maintained at 30 to $31^{\circ} \mathrm{C}$. Water salinity, $\mathrm{pH}$ and DO were 31 to $33 \mathrm{ppt}, 7.8$ to 8 , and 5 to $7 \mathrm{mg} / \mathrm{l}$, respectively. Eggs diameter ranged from 0.550 to $0.603 \mathrm{~mm}$. At 1 day after hatched (d AH), ey es of the larvae were formed but unpigmented and mouth structure was not developed. At $2 \mathrm{~d}$ AH, the pigmentation of eyes darkened, digestive tract formed, and anus and mouth opened. At $3 \mathrm{~d} \mathrm{AH}$, the lower jaw began to show movement, indicating that the ability of larvae to indulge in feeding. The buds of dorsal and ventral fins started to develop and elongate from $9 \mathrm{~d} \mathrm{AH}$ and were covered with melanophores. At $25 \mathrm{~d} \mathrm{AH}$, the body of the larvae turned brownish and abdominal cavity was deeply pigmented, indicating the onset of metamorphosis. By the age of $30 \mathrm{~d} \mathrm{AH}$, the larvae completed development into juvenile stage. At $270 \mathrm{~d}$ AH, the juvenile reached maximum size of $21 \mathrm{~cm}$ in total length. This study was the first successful attempt at naturally spawning and hatchery rearing of S. javus into juv enile stage in the country. The development of a complete larval rearing protocol for $S$. javus could provide information of practical importance in hatchery breeding of other rabbitfish species.
\end{abstract}

Keywords: Siganus javus, Hatchery, Captive breeding, Sabah

\section{Introduction}

Rabbitfish (Siganus spp.), or spinefoot are nutritionally important fish with economic value in several Indo-Pacific countries and Eastern Mediterranean nations (FAO, 2020). Their main identical features are the venomous spines along the fins and changing colour to a mottled pattern during rest and when under stressed condition. The venomous spines can cause sharp pain, bleeding and numbness but there are probably no reported cases of death of the victims of attack. They are often seen in a school when foraging the seagrass beds and algal flats, whereas some pair-bonding species are often seen on coral reefs (Seale and Ellies, 2019).

Rabbitfish has received attention inaquaculture due to its environmental resilience and ability to tolerate conditions of captivity. It has a remarkable tolerance to crowded conditions, readily accepts artificial diets, and due to its low tropic level, the fish requires less protein or inexpensive feeds (Tabugo et al., 2012). Rabbitfish can be cultured in either brackish water ponds or in marine floating net cages (Rachmansyah et al., 1997). Attempts to breed rabbitfish in captivity were first reported by Manacop (1937) and then by Fujita and Ueno (1954). Many studies on breeding of rabbitfish reported difficulties in larval rearing especially during early stage of development (Popper etal., 1973; Soh and Lam, 1973; Westernhagen and Rosenthal, 1975; Bryan and Madraisau, 1977), due to unavailability of suitable feed for the initial larval stage (Juario et al., 1985; Rachmansyah etal., 1997; Huang et al., 2018).
Traditional farming of rabbitfish has existed in Guam and the Philippines (Duray, 1998). In Malaysia, rabbitfish are often caught using trawls and traps, and are mostly landed in Sabah (MYAgro, 2020). However, no hatchery or farming of rabbitfish has been reported in Malaysia. The private sector aquaculture farms are focusing on the culture of highly commercial value species that are carnivorous fish, such as grouper and seabass. Rabbitfish is considered a fav ourite fish and is consumed by the local population, particularly in the state of Sabah. It is considered palatable and affordable. It has tender flesh and less bones (Ben-Tuvia et al 1973; Lam 1974; Putro et al. 1985; Darsono, 1993). The fish contains rich amounts of highlyunsaturated fatty acids or HUFA) (Huang et al., 2018). According to Wahyuningtyas et al. (2017), rabbitfish flesh contained $77.79 \%$ moisture, $15.93 \%$ protein, $0.93 \%$ fat, and 16 amino acids, including nine essential and seven non-essential aminoacids.

Rabbitfishes are not considered a high market value fish in most countries. However, in some remote South Pacific islands such as New Caledonia, it is sold for USD1418/kg (FAO, 2020). In Singapore, rabbitfish can fetch up to 20 SGD (equal to 60 MYR) per kilo and the price may increase to 80 SGD per kilo during Lunar New Year peri od (PickMe, 2021). This shows that the market demand for rabbitfish can be developed not only for local consumption but also for export. The presentstudy by Bayu Aquaculture Sdn. Bhd. aims to expand the market potential of rabbitfish and provide consumers more choices of affordable protein from farmed fish. 


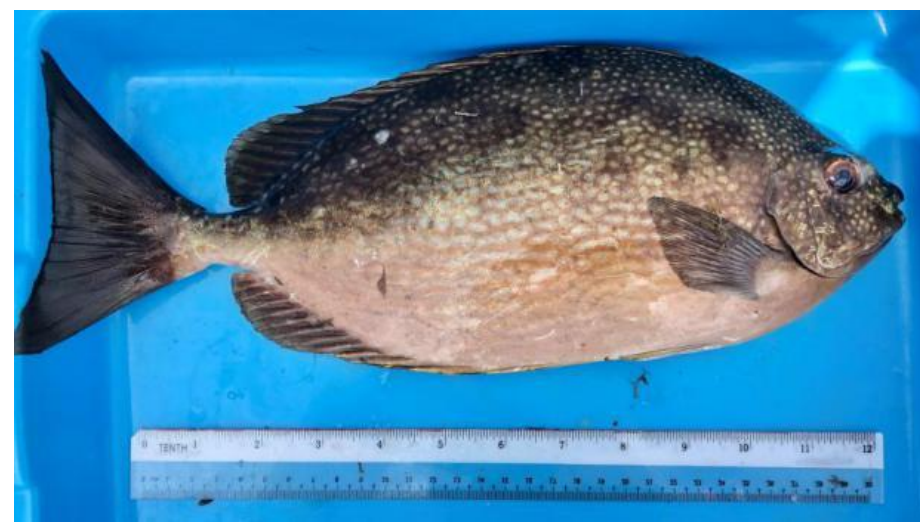

Figure 1. Wild caught Streaked spinefoot rabbitfish (Siganusjavus).

Siganus javus (Figure 1) is one of the more abundant and commercially important rabbitfish species in Malaysia. It is locally known as "ikan dengkis jawa" or "belais". This fish has many small white spots on the upper side of the body and fine longitudinal lines on the lower part. The head and fins are often yellow, and the tail fin is dark. Adult size ranges between 25 and $55 \mathrm{~cm}$ in total length. They live in marine and brackish water, and some may enter river, lakes and harbour (De Beaufort and Chapman, 1951; Herre, 1953; Kurup and Samual, 1985; dela Paz and Aragones, 1990). Chemical analysis of $S$. javus shows relatively high protein content (Peiris and Grero, 1972), supporting the potential of this species being cultured commercially.

\section{Materials and Methods}

\section{Broodstock and spawning}

Adult male and female specimens of the fish were collected abouta week before new moon from Gaya Island, Sabah by using fish traps. Only the bigger size of the brood fish (each weight 100 to $250 \mathrm{~g}$ and above, $30 \mathrm{~cm}$ in total length) was selected for the breeding purpose. The broods were kept in the hatchery of Marine Ecology Research Centre in Gaya Island and conditioned in a three-meter diameter and one meter depth round tank, with 24-hour aeration and continuously running seawater (water exchange rate above $100 \%$ per day) to maintain good water quality and circulation. Water temperature, $\mathrm{pH}$ and salinity were maintained at 28 to $30{ }^{\circ} \mathrm{C}, 7.8$ to 8 , and 31 to $33 \mathrm{ppt}$, respectively. About half of the water in tank was releas ed daily in the morning and refilled back in the evening to trigger the broods to spawn.

The broods were fed twice a day with enriched diet such as squid, trash fish and formulated feed. Prior to spawning, females with swollen abdomen and mal es with milt were selected and separated evenly into different tanks. In this study, nine pairs of broods (sex ratio 1:1) were selected and separated into three similar round tanks (three pairs per tank). Since the eggs are demersal and adhesive, few pieces of old PVC pipes and nylon net (half inch mesh size) were placed inside each tank for eggs attachment.
After conditioning for about 2 weeks, spawning activities were recorded in a week after new moon in October 2019 and January 2020. The eggs were laid between midnight and early morning. The broods were removed from the tank after spawning to avoid filial cannibalism. The fertilized eggs were left in the spawning tank for incubation. Slow running water (approximately one litre per hour) was allowed to remove the excess milt and turned off in the evening to prevent the hatching larvae from overflowing out from the tanks.

\section{Eggs incubation and larval rearing}

Fertilized eggs were incubated in the same tank used for spawning. The tanks were filled with approximately 1500 litre of water with 24 hours aeration. Throughout the incubation period, a heater was placed in each inc ubati on tank to maintain the water temperature at 30 to $31^{\circ} \mathrm{C}$. Water salinity, pH and DO were 31 to 33 ppt, 7.8 to 8 , and 5 to 7 $\mathrm{mg} / \mathrm{l}$, respectively. Upon hatching, the larvae were packed and transferred to the fish farm of Bayu Aquaculture Sdn. Bhd. in Tuaran, Sabah.

Table 1. Feeding schedule of $S$. javus during larvae rearing.

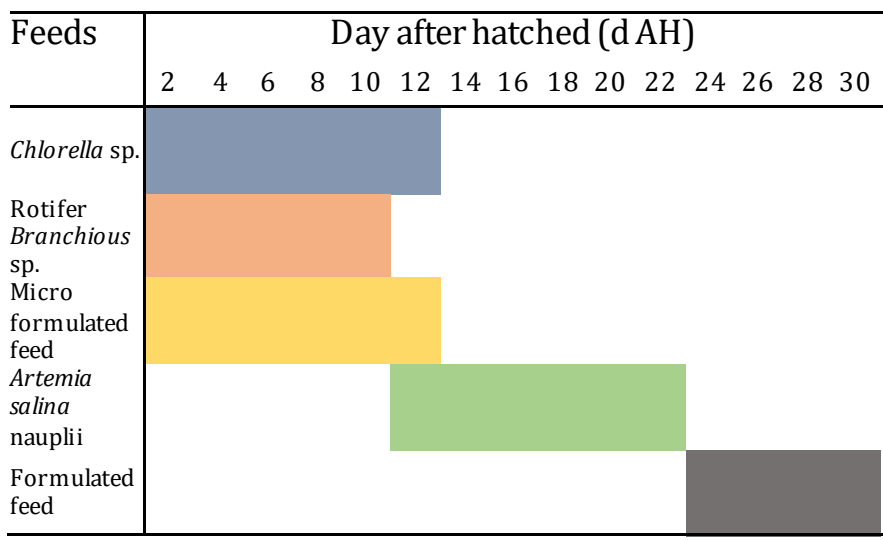

The larvae were adjusted to the desired stocking density and reared in the $15 \mathrm{~m} \mathrm{x} 6 \mathrm{~m} \times 1.3 \mathrm{~m}$ concrete pond with 24-hour aeration, and later graded by size and transferred to round tank filled with two to four tonne of seawater after grading. The feeding schedule of the S. javus in larval stages is shown in Table 1. The larvae were fed with different diets three times a day, including Chlorella sp., rotifer Brachious sp., commercial brine shrimp Artemia salina nauplii and formulated feed, Otohime (Marubeni Nisshin Food). Newly hatched larvae relied on eggyolk sac on day 1 to 2 day after hatched ( $\mathrm{d} \mathrm{AH}$ ), and start feeding from day 2 after the mouth and digestion system is fully developed. Total length (TL) of larvae were measured from $0 \mathrm{~d}$ AH. Eggs and larval development were observed under stereo microscope (Motic SMZ-171) and photographs were taken with a digital microscope camera (Moticam 5+). 


\section{Results}

\section{Eggs development}

The female laid small, spherical, transparent eggs that are externally fertilized by sperm. The eggs contain multiple oil globule that coalesce as development proceeds and only one or two oil globules remain before hatching. Eggs dia meter ranged from 0.550 to $0.603 \mathrm{~mm}$ in this study. Spawning occurred between midnight and early morning, and the eggs hatched about 16 to 18 hours later. The adhesive demersal fertilized eggs were attached to the wall of the tank, on the PVC pipe and nylon nets placed in the tank, and to the aeration tube. This caused difficulty in estimating the number of eggs that had been laid. Hatching rate was roughly estimated at $90 \%$.
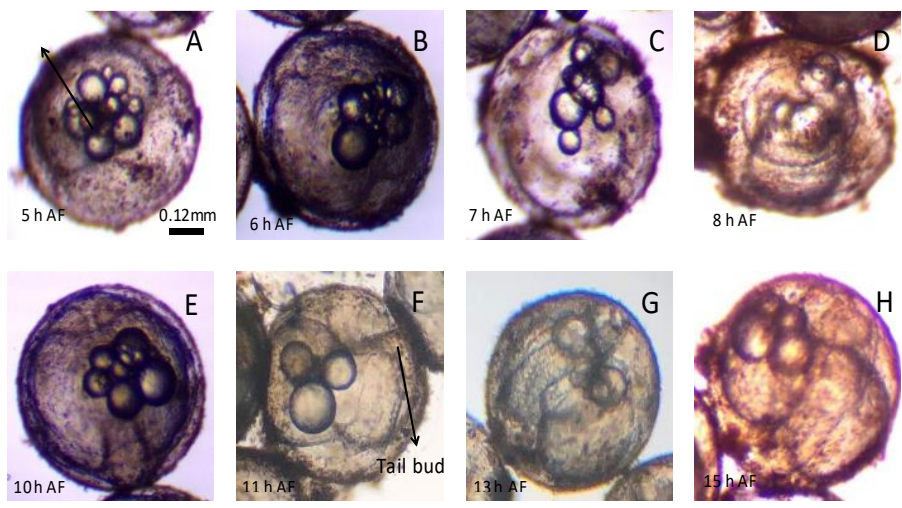

Figure 2. Embryonic development of $S$. javus after fertilization. A. Mid blastula; B. Late blastula; C. Early grastula; D. Late grastula; E. Neurula; F. Tail bud formation; G. Organ formation; $\mathrm{H}$. Muscle contraction; all scale are the same as shown in $\mathrm{A}$ at bottom right corner.

The embryonic development of S.javus was shown in Figure 2. After fertilization, the eggs undergo rapid cell divisions. Upon reaching the 16-cell stage in about 1 hour after fertilization (h AF), blastomeres reduced in size and the eggs entered the morula stage. In this period, successive cleavage occurs, blastomeres became crowded cells and blastodisc looked more like a ball. After the cleavage has produce over 100 cells, the eggs entered the blastula stage (4 $\mathrm{h} A F)$. In this period, the epiboly was formed and continued until grastrula stage ( $7 \mathrm{~h} \mathrm{AF}$ ). During gastrulation, germ ring and embryonic shield were formed. The blastomeres extended to cover the epiboly, with number of oil globul es greatly reduced and embryo body was formed. The development continues with neurulation and the formation of organ until hatching at 16 to $18 \mathrm{~h} \mathrm{AF}$.

\section{Larval development}

The larvae morphological changes and juvenile development of S. javus are illustrated in Figure 3 and 4, respectively. Total length (TL) changes of larvae are shownin Figure 5. At 1 day after hatched $(\mathrm{d} \mathrm{AH})$, the larvae eyes were formed but unpigmented and mouth still unformed, thus relying on yolk sac for nutrient (Figure 3A). Larvae have melanophores on the snout, yolk and oil globules, and along the ventral side of body. At $2 \mathrm{~d} \mathrm{AH}$, the larvae eyes pigmentation darken, digestive tract formed, anus and mouth opened (Figure 3B). At $3 \mathrm{~d} \mathrm{AH}$, yolk sac was absorbed and the oil globule diminished to negligible size, the lower jaw began to move, indicating the larvae ability to start feeding. At $3 \mathrm{~d} \mathrm{AH}$, the larvae TL averaged $2.47 \mathrm{~mm}$ and mouth was $0.10 \mathrm{~mm}$ in width. Chlorella sp., rotifer Branchious sp. and micro formulated feed were being introduced as their starting diet. At $4 \mathrm{~d} \mathrm{AH}$, the larvae's stomach was full and golden-brown in colour, indicating the larvae were well fed and the feed given were accepted.

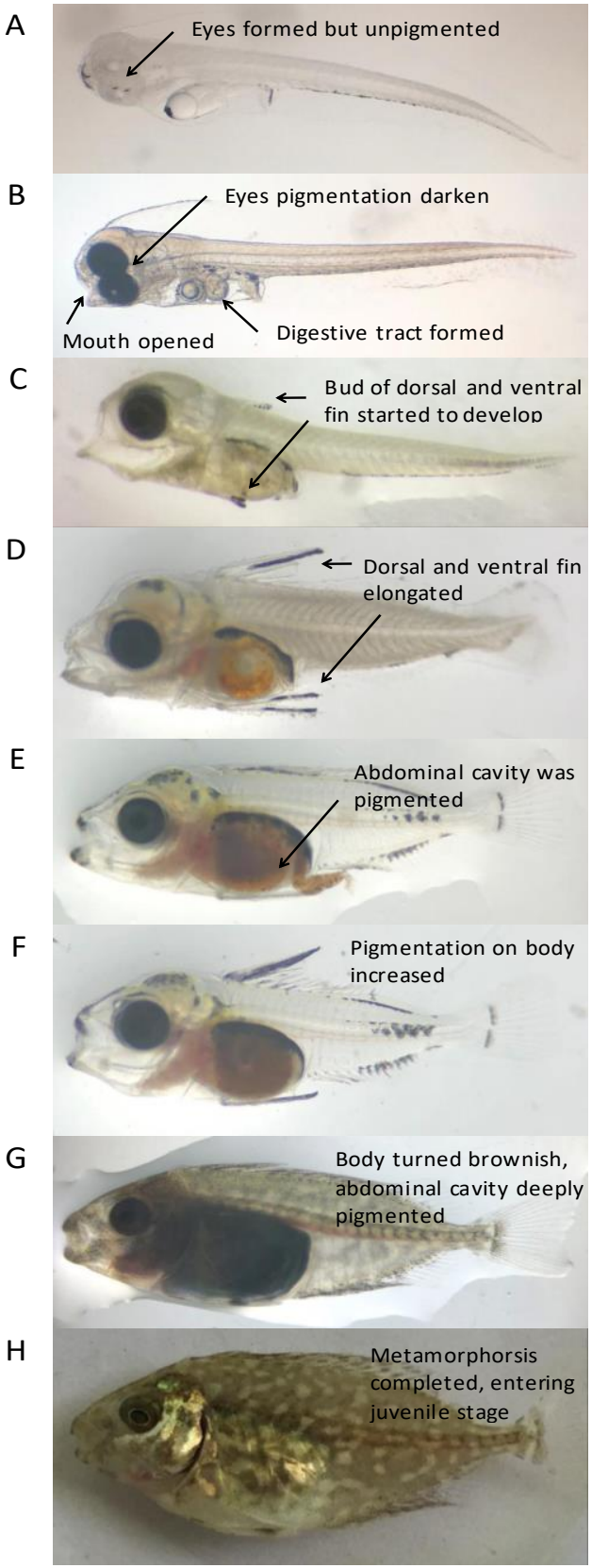

Figure 3. Morphological changes of $S$. javus in larvae stage. A $1 \mathrm{~d} \mathrm{AH}, 2.37 \mathrm{~mm}$ TL; B. $2 \mathrm{~d} \mathrm{AH}, 2.47 \mathrm{~mm}$ TL; C. $9 \mathrm{~d} \mathrm{AH}, 4.22$ mm TL; D. 11 d AH, 5.0 mm TL;E. 15 d AH, 7.92 mm TL; F. 18 d AH, 13.5 mm TL; G. 25 d AH, 23.0 mm TL; H. 30 d AH, 26.0 $\mathrm{mm}$ TL 
The bud of dorsal and ventral fin started to develop and elongate from $9 \mathrm{~d} \mathrm{AH}$ and were covered with melanophores (Figure 3C). At $13 \mathrm{~d} \mathrm{AH}$, the larvae reach ed $6.27 \mathrm{~mm}$ in TL and actively fed on Artemia salina nauplii. The abdominal cavity was pigmented and coloured. Pigmentation or melanophores were seen on lateral line and posterior part of dorsal and anal fins. Melanophores increased from $15 \mathrm{~d} A H$ (Figure 3E) onwards and spread to other parts of body, including the head part, lateral line, and caudal fin in $18 \mathrm{~d} \mathrm{AH}$ (Figure 3F). Larvae started to exhibit schooling behavio ur and were observed swimming in group. At $25 \mathrm{~d} \mathrm{AH}$, the larvae body turned brownish and abdominal cavity was deeply pigmented, indicating the onset of metamorphosis (Figure 3G).

By the age of $30 \mathrm{~d} \mathrm{AH}$, the larvae completed metamorphosis and started showing the juvenile morphological features. The fish body was no longer transparent, the body shape and col oration resembled those of the adult, and all the fins were complete well developed (Figure 3H). The completion of metamorphosis indicated the fish is entering juvenile stage. Survival rate of larvae reared to metamorphosis was approximately $15 \%$. At $120 \mathrm{~d} \mathrm{AH}$, the juvenile reached $11 \mathrm{~cm}$ in TL with small white spots on the upper side of the body and fine longitudinal lines on the lower part of the body clearly seen (Figure 4A). At $150 \mathrm{~d} \mathrm{AH}$, the juvenile reached $13 \mathrm{~cm}$ in TL, active and responding well to formulated feed given (Figure 4C). At $270 \mathrm{~d} \mathrm{AH}$, the juvenile reached $21 \mathrm{~cm}$ in TL (Figure 4D).
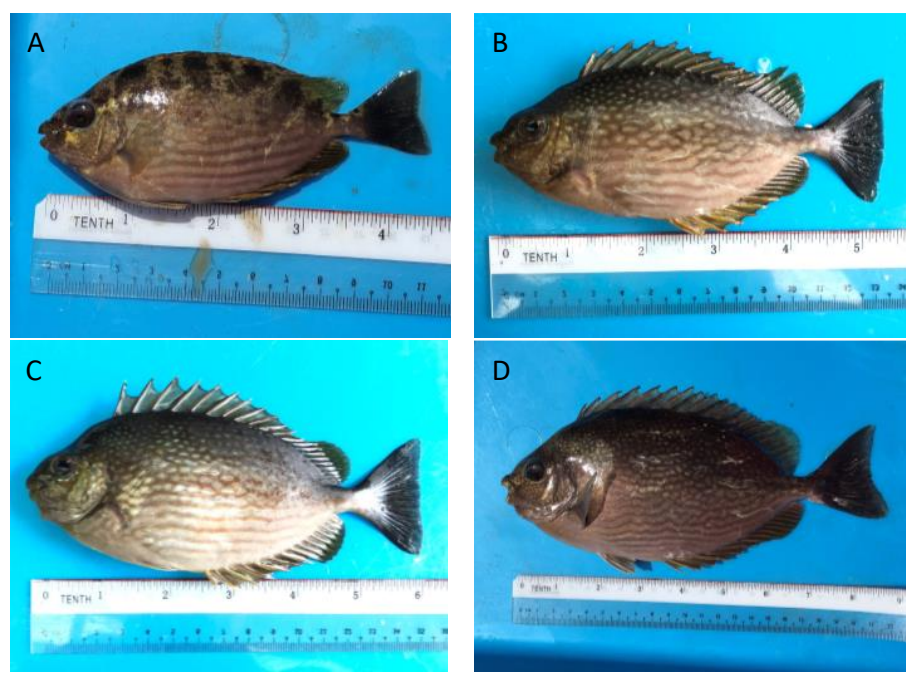

Figure 4. Juvenile development of S. javus. Body colour and pattern resemble of the adult. A. $120 \mathrm{~d} \mathrm{AH}, 11 \mathrm{~cm}$ TL; B. $150 \mathrm{~d}$ AH, $13 \mathrm{~cm}$ TL; C. $200 \mathrm{~d}$ AH, $15 \mathrm{~cm}$ TL; D. $270 \mathrm{~d} \mathrm{AH}, 21 \mathrm{~cm} \mathrm{TL}$.
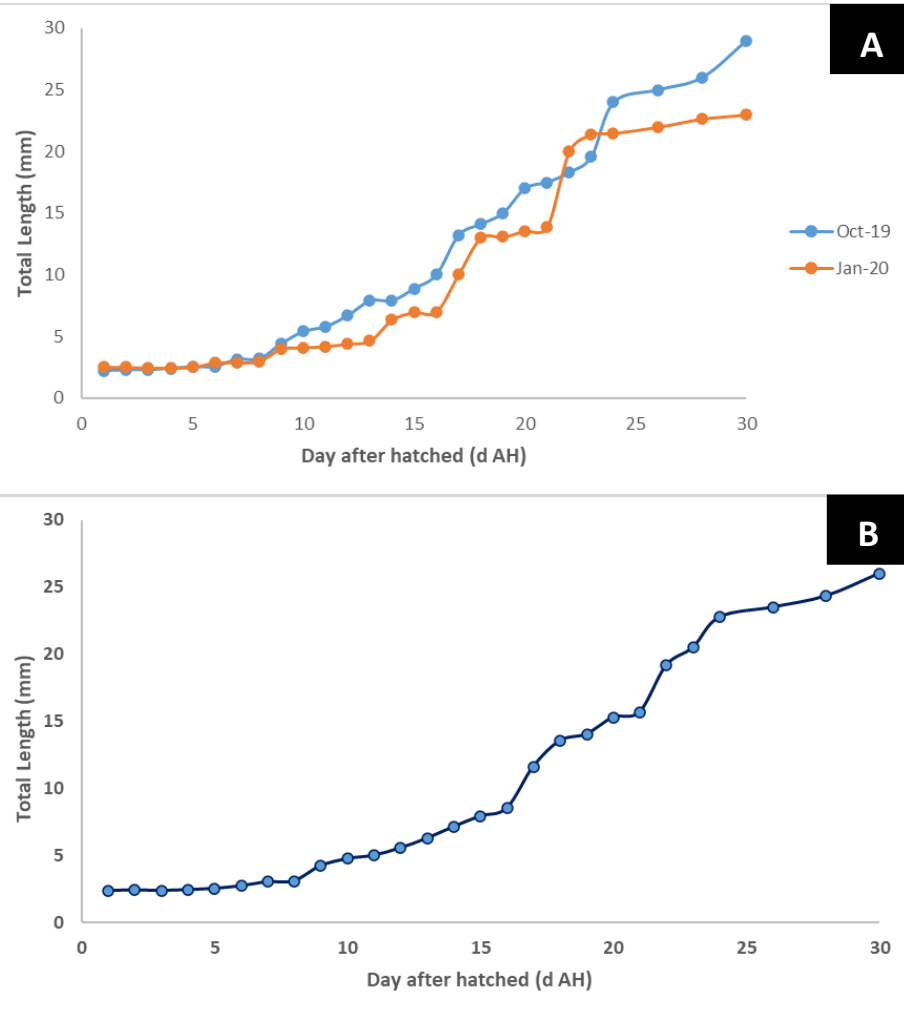

Figure 5. A) Average growth of S. javus from 2 different batches (October 2019 and January 2020). B) General average growth (TL) of $S$. javus larvae from 0 to $30 \mathrm{~d} \mathrm{AH}$.

\section{Discussion}

\section{Spawning}

In this study, S.javus broods were collected before new moon and natural spawning occurred a week after new moon. Rabbitfish are lunar cycle spawner and exhibit lunar spawning rhythm (Lam,1974). According to Rahman et al. (2004), the gonadal development and the hormonal fluctuation of the rabbitfish are repeated at an interval of one month according to the lunar cycle. However, the lunar phase for timing of synchronous spawning is different among species (Takemura et al., 2004). Thus, hormonal treatment may not be necessary if spawning is attempted on the right days of lunar month (Darsono, 1993). In nature, each rabbitfish species exhibits a definitive reproductive season, which differs by tropical region.

Water in tank holding S. javus broods was released in the morning and refilled back in the evening to trigger spawning. According to Duray (1990), other than specific lunar phases, the spawning of rabbitfish is also synchronously linked to tides. McVey (1972) mentioned that tidal level is the most important factor in the spawning of rabbitifsh. Laviña and Alcala (1974) reported spawning of rabbitfish at night in the open water near the surface of Southen Negros, Philippines. The advantage of these strategies may minimize immediate egg and larval predation, by facilitate their transportation to offshore by the strongest outgoing tide (Thresher, 1984). 
The broods of $S$. javus in this study were fed with squid, trash fishand commercial pellet during preparation for spawning. Rabbitfish are mainly herbivores in nature. They feed on benthic algae, seaweed and seagrass. How ever, in captivity, rabbitfish can be easily weaned on to formulated feeds (Li et al., 2018). Lam (1974) stated that rabbitfish, which are herbivorous in nature, will become omnivorous in captivity. Early maturity and year-round spawning has been recorded in captivity where rabbitfishes were fed with nutritional artificial diets. (Lam, 1974; Hara et al, 1986; Takemura et al., 2004).

\section{Embryonic and larval development}

Similar to other rabbitfish species, fertilized eggs of $S$. javus observed in this study were small, spherical, trans parent, demersal and adhesive, and contained multiple oil gl obules. Unlike other marine fin fishes which produce mostly pelagic and non-adhesive eggs, the characteristics of the rabbitfish eggs are similar to most freshwater fish that produce adhesive eggs which stick on rock or gravel, weed or s and. The fertilized eggs of $S$. javusin this study were ranged from 0.550 to $0.603 \mathrm{~mm}$ in diameter and took about 16 to 18 hours to hatch at 30 to $31^{\circ} \mathrm{C}$. In general, rabbitfish eggs measured 0.42 to $0.70 \mathrm{~mm}$ in diameter and took 18 to 35 hours to hatch at 22 to $30^{\circ} \mathrm{C}$ (Lam, 1974; FAO, 2020). Hatching time of rabbitfish eggs is variable, depending on temperature and perhaps on the species and locality (Lam, 1974). For example, S. canaliculatus eggs measured $0.58 \mathrm{~mm}$ in diameter took 39 to 42 hours to hatch at 23.2 to $24.5^{\circ} \mathrm{C}$ (Huang et al., 2018), $S$. vermiculatus eggs measured $0.56 \mathrm{~mm}$ in diameter to ok 25 hours 30 minutes to hatch at 27 to $29^{\circ} \mathrm{C}$ (Anuraj et al., 2019), and $S$. randalli eggs measured 0.51 to $0.58 \mathrm{~mm}$ in diameter took 18 to 21 hours to hatch at 26 to $28{ }^{\circ} \mathrm{C}$ (Nelson and Wilkins, 1994). The temperature for eggs incubation in this study was slightly higher compared to the above studies, which probably contributed to the shorter time S.javus eggs took to hatch.

Newly hatched larvae were pelagic, and they have small yol ksac containing one oil globule. The larvae began to develop into juveniles stage at 25 to $30 \mathrm{~d}$ AH, with 23 to 26 $\mathrm{mm}$ in total length. The results are similar with the study conducted by Darsono (1993), stating duration of the planktonic stage of rabbitfish is about 25 days, with juv enile fish between 20 and $26 \mathrm{~mm}$ long. However, the time taken for the larvae to metamorphose into juveniles depends on the species; 24 to 35 days in S. guttatus (Juario et al., 1985), 23 to 30 days in S. canaliculatus (May et al., 1974), 23 to 25 days in S. vermiculatus (Gundermann et al., 1983) and 29 to 35 days in S. lineatus (Bryan and Madraisau, 1977). The proc ess of metamorphosis include changes in colouration, behavior, and feeding habit (Gundermann et al., 1983). The end of the larval stage is marked by a metamorphosis process, more or les $\mathrm{s}$ abrupt depending on the species, during which the larva becomes a juvenile that is morphologically si milar to the adult and has the meristic characters of the species.
In this study, Chlorella sp., rotifer Branchious sp. and micro formulated feed were introduced as the diet starter for S. javus larvae. The larvae mouth was formed in $2 \mathrm{~d} \mathrm{AH}$ with the opening size of only $0.10 \mathrm{~mm}(100 \mu \mathrm{m})$. Thus, the larvae only able to consume the smallest rotifer Branchious sp. with size less than $100 \mu \mathrm{m}$. This poses a problemas only small amount of the rotifer fed to the larvae constitutes this size group. Due to this, Chlorella sp. (3 to $8 \mu \mathrm{m}$ ) and micro formulated feed ( 75 to $150 \mu \mathrm{m}$ ) were also added as starter feed.

According to Rachmansyahetal. (1997), the main constraint faced in rabbitfish larval rearing is the availability of suitable size and quality of feed for day one to five larvae. Similarly, Stephanou and Georgiou (2000) also encountered the same problem during feeding of early stage of larvae (day 2 to day 6) due to their small mouth size. They concluded that the size of the prey is the limiting factor and that rotifer and phytoplankton alone cannot support larval survival. The mouth size of newly hatched rabbitfish larvae were smaller compared to other commonly cultured marine fin fish larvae such as grouper and seabass. Thus, diet particles must be chosen with consideration to the small mouth size of fish larvae. Appropriate feed is important to increase the survival rate and quality of the juveniles (Rachmansyah etal., 1997). Success of larval rearing depends mainly on the availability of suitable diets that can be readily consumed, efficiently digested and that provide the required nutrients to support good growth and heal th (Giri etal., 2002).

Although rabbitfish has long been identified as appropriate candidates for aquaculture, hatchery breeding of rabbitfish in captivity is still consider relatively new. Rabbitfish is abundant during its recruitment periods, making it easy to catch in the shallows and thus keeping down the costs of acquiring fingerlings (Teitelbaum et al., 2008). Due to this, fish farmers preferably practice capturebased aquaculture to collect the rabbitfish fingerlings rather than obtain the fingerlings through full breeding cycle. Capture-based aquaculture does not rely on controlling the reproduction and breeding of farmed species, but it could be considered as an unsustainable aquaculture practice, due to the increasing pressure on fish stocks that could cause successive stock depletion, low recruitment, stock collapse, and reductions in genetic biodiversity (Ottolenghi et al., 2004). Full cycle breeding, on the other hand, provides genetic improvement, food security and an additional income source to rural communities (Lovatelli and Holthus, 2008). Besides, the fact that rabbitfish are herbivorous fish giv en advantages in terms of energy transformation (high nutrient quality) and resource utilization (low production cost) compared to carnivorous fish species (Li etal., 2018), making rabbitfish a promising aquaculture candidate. 


\section{Conclusion}

This study concluded the early successful naturally spawning and hatchery rearing of $S$. javus to juveniles stage in the country. This is a major breakthrough achievement in the seed production of rabbitfish. The successful devel opment of a complete larval rearing protocol for $S$. javus could provide information for hatchery breed of other rabbitfish species in the country. A continuous and sufficient supply of hatcherybreed rabbitfish would support market demands and reduce dependence on wild-caught juveniles to achieve more sustainable aquaculture practice.

\section{Acknowledgement}

I thank Datuk Robert Tan and Bayu Aquaculture Sdn. Bhd. for financing and supporting this trial. My appreciation to $\mathrm{Mr}$. Ling Ming Woo and his team for assistance in the trial and to Ms. Ong Fang Sing for preparation of manuscript.

\section{References}

Anuraj, A., Suresh Babu, P.P., Loka, J., Rao, S., K., Dube, P., Sonali, S.M., Pramila, H.B., Khumbar, N., Joseph, I. \& Ignatius, B. (2019). First report on induced spawning of Siganus vermiculatus in India. Marine Fisheries Information Service Technical \& Extension Series 239, 11-13.

Ben-Tuvia, A., Kissil, G.W. \& Popper, D. (1973). Experiments in rearing rabbitfish (Siganus rivulatus) in sea water. Aquaculture 1, 359-364.

Bryan, P.G. \& Madraisau, B.B. (1977). Larval rearing and development of Siganus lineatus (Pisces. Siganidae) from hatching through metamorphosis. Aquaculture 10 (3), 243-252. DOI: 10.1016/00 44-8486(77)90005-9.

Darsono, P. (1993). Culture potential of rabbitfishes, Siganus (siganidae). Oseana 18(1), 1-24.

De Beaufort, L.F. \& Chapman,W.M. (1951).Sub order Sigan oidea (Family Siganidae). In: The Fishes oftheIndo-Australian Archipelago IX. pp. 95 125. Leiden E.J. Brill Ltd., A.J. Reprints Agency, New Delhi.

De La Paz, R.M. \& Aragones, N.V.(1990). Abundance and seasonality of Siganid fishes (Teleostei, Perciformes) in Cape Bolinao, Pangasinan, Philippines. Philippines Journal of Science 19, 223-225.

Duray, M.N. (1998). Biology and Culture of Siganids. Aquaculture Department, Southeast Asian Fisheries Development Center (SEAFDEC). pp. 53 Tigbauan, Iloilo, Philippines.

FAO (2020). Cultured aquatic species information programme Siganus spp. Food and Argricultural Organization, Fisheries Division, Rome.

Fujita, S. \& Ueno, M. (1954). On the development of the egg and prelarval stages of Siganus fuscescens (Houttuyn) by artificial insemination. Japanese Journal of Ichthyology 3,129-132. DO I: 10.11369/JJ19503.129.

Giri, S.S., Sahoo, S.K., Shu, B.B., Sahu, A.K., Mohanty, S.N., Mohanty, P.K. \& Ayyapan, S. (2002). Larval survival and growth in Wallago attu (Bloch \& Schneider): effect of light, photoperiod and feeding regimes. Aquaculture 213,157-161. DOI: 10.1016/S0044-8486(02)00012-1.

Gundermann,N.,Popper,D.M. \& Lichatowich, T. (1983). Biology and life cycle of Siganus vermiculatus (Siganidae, Pisces). Pacifific Science37, 165180.

Hara, S., Duray, M.N., Parazo, M. \& Taki, Y. (1986). Year-round spawning and seed production of the rabbitfish, Siganus guttatus. Aquaculture 59, 259-272.D OI: 10.1016/0044-8486(86)90008-6

Herre, A.W. (1953). Family 153. Teuthidida e (Siganidae). In: Checklist of Philippine Fishes. pp. 552-562. Research report/ U.S. Fish and Wildlife Service no. 20, Washington, United States Office.
Huang, X., Li, T., Lin, H.,Yang, Y.,Yu, W. \& Huang, Z. (2018). Observation on embryonic development of cage-breeding Siganus oramin. South Chine Fisheries Science 14(2), 96-101.

Kurup, B.M. \& Samuel, C.T. (1985). A re-description of the little known rabbitfish Siganus lineatus (Cuvier \& Valen ciennes) (Pisces: Siganidae) with notes on siganidsfishes of the Vembanad Lake. FisheryTechnology 22,6265.

Juario, J.V., Duray, M.N., Dwray, V.M., Nacario, J.F. \& Almendras, J.M.E. (1985). Breeding and larval rearing of the rabbitfish, Siganus guttatus (bloch). Aquaculture 44, 91-101DOI:. 10.1016/0044-8486(85)90012-2.

Lam, T.J. (1974). Siganids: their biology and mariculture potential. Aquaculture 3, 325-354.DOI: 10.1016/0044-8486(74)90001-5.

Laviña, E. \& Alcala, A.C. (1974). Ecological studies on the Philippine siganid fish esin Southern Negros, Philip pines. Silliman Journal 21(2),191210.

Li, Y., Zhang, Q. \& Li, Y. (2018). Rabbitfish - an Emerging Herbivorous Marine Aquaculture Species. In: Aquaculture in China: success stories and modern trends, first edition. (Gui, J., Tang, Q., Li, Z., Liu, J. \& De Silva, S.S., eds.) pp. 329-334. John Wiley \& Sons Ltd. DOI: $10.1002 / 9781119120759 . c h 3 \_12$.

Lovatelli, A. \& Holthus, P.F. (2008). Capture based aquaculture: global overview. pp. 298. FAO Fisheries Technical Paper No. 508. FAO Rome.

Manacop, R.R. (1937). The artificial fertilization of dangit, Amphacanthus oramin (Bloch \& Schneider). Philippine Journal ofScience 62, 229-237.

May, R.C., Popper, D. \& Mcvey, J.P. (1974). Rearing and larval development of Siganus canaliculatus (Park) (Pisces: Siganidae). Micronesica 10, 285- 298.

McVey, J.P. (1972). Observations of the early-stage formation of rabbitfish Siganus fuscescens at Palau Mariculture Demonstration Center. South Pacifific Island Fisheries Newsletter 6, 1-12.

MYAgro (2020).Ikan dengkis. Ministry of Agriculture. Retrieved from http://portal.myagro.moa.gov.my/ms/d of/cfsh/Pages/Dingkis.aspx.

Nelson, S.G. \& Wilkins, S.D. (1994). Growth and respiration of embryos and larvae of the rabbitfish Siganus randalli (Pisces, Siganidae). Journal of Fish Biology 44, 513-525. D0I: 10.1111/j.1095-8649.1994.tb01230.x.

Ottolenghi, F., Silvestri, C., Giordano, P.,Lovatelli, A. \& New, M.B. (2004). Capture-based aquaculture: The fattening of eels, groupers, tunas and yellowtails. Food and Agricultural Organization of the United Nations. pp. 308. FAO Rome.

Peiris, T.S.S. \& Grero, J.(1972).Chemical analysis of some Ceylon fishes2. Bulletin of the Fisheries Research Station Sri Lanka 23 (1 \& 2), 1-7.

Popper, D., Gordin, H. \& Kissil, G.W. (1973). Fertilization and hatching of rabbitfish Siganus rivulatus. Aquaculture 2, 37-44. DOI: 10.1016/004 48486(73)90124-5

Putro, S., Saleh, M. \& Utomo, B.S.B. (1985). Storage life of rabbitfish (Siganus sp.) during icing. FAO Fish Report 317, 54-61.

Rachmansyah,Usman, Lante, \& S., Ahmad, T.(1997).Rabbitfish Siganus guttatus breeding and larval rearing trial. Aquaculture Asia Magazine 11(3), 39-40.

Seale,A.P. \&Ellies, S. (2019). Sustainable Capture-Based Aquaculture of Rabbitfish in Pacific Island Lagoons. Aquaculture and Aquaponics 1, 1-9.

Soh,C.L. \& Lam, T.J. (1973).Induced breeding and early development of the rabbitfifish Siganus oramin (Schneider) $(=S$. canaliculatus). Proceedings of the Symposium on Biological Researches and National Development, 49-56.

Stephanou, D. and Georgiou, G. (2000). Recent experiences on the culture of rabbitfish Siganus rivulatus in Cyprus. Recent advances in Mediterranean aquaculture finfish species diversification. Zaragoza: CIHEAM, p. 295-301 (Cahiers Options Méditerranéennes; n. 47). 
Volume: 05 (01) | Nov 2021, 01-07

Tabugo, S.R.M., Sendaydiego, J.P., Requieron, E.A. \& Dimalen, M.D. (2012). Embryonic developmental stages in cultured rabbitfish (Siganus guttatus, Bloch 1787). International Research Journal of Biological Sciences 1(8), 65-70.

Takemura, A., Rahman, M.S., Nakamura, S., Park, Y.J. \& Takano, K. (2004). Lunarcycles and reproductive activityin reeffish eswith particular attention to rabbitfishes. Fish and Fisheries 5, 317-328.DOI: 10.1111/j.1467-2679.2004.00164.x.

Teitelbaum, T., Pryor, T., Legarrec, F., Oengpepa, C. \& Mesia, P. (2008). Rabbitfish: A candidate for aquaculture in the Pacific? In: SPC Fisheries Newsletter no.127 (Gaudechoux, J.P. ed.), pp. 40-44.

Thresher, R.E. (1984). Reproduction in Reef Fishes. pp. 399. T.F.H. Publications, Neptune City, New Jersey.

Westernhagen, H. \& Rosenthal, H. (1975). Rearing and spawning siganids (Pisces: Teleostei) in a closed seawater system. Hetgoländer wiss. Meeresunters 27, 1-18. 